\title{
ORGANOLEPTIC ANALYSIS OF YOGURT WITH BANANA ADDITION AND STEVIA SWEETENERS
}

\author{
M. Faisal*, Saifullah and T. Mukhriza \\ Department of Chemical Engineering, Syiah Kuala University, Banda Aceh, 23111, Indonesia \\ *E-mail: mfaisal@unsyiah.ac.id
}

\begin{abstract}
Food product consumers today expect to benefit from the nutritional value of certain food products; hence, the products are often referred to as functional food. Yogurt is a functional food product obtained from fermented milk. Various yogurt products were developed to meet nutritional needs without having negative effects on the body. This study assesses the quality of yogurt produced after adding a kepok banana (Musa paradisiaca formatypical) and stevia sweetener. In this study, yogurt was made by fermenting cow's milk with Lactobacillus bulgaricus and Streptococcus thermophillus bacterial starters for four to eight hours at $42^{\circ} \mathrm{C}$. Stevia sweetener and flavourings from kepok banana were then added. The results showed that both the lactic acid and $\mathrm{pH}$ of the yogurt met the Indonesian national quality standards for yogurt. Organoleptic testing showed that most panellists liked the product. Hedonic values for colour, texture, aroma, and taste were 4.05; 4.35; 4.3; and 4.4, respectively.

Keywords: Yogurt, Musa paradisiaca formatypical, Organoleptic, Hedonic, Stevia, Diabetes mellitus
\end{abstract}

(C) RASĀYAN. All rights reserved

\section{INTRODUCTION}

Among the food products widely developed as functional foods are probiotic products. Probiotics, taken as a daily supplement, are live bacteria that promote good health. ${ }^{1,2}$ One of the probiotic products containing lactic acid bacteria is yogurt, which is a milk coagulation food item produced through the fermentation process of specific lactic acid bacteria, such as Streptococcus thermophiles and Lactobacillus delbrueckii ssp. bulgaricus. ${ }^{1,3,4}$ Yogurt has been widely accepted by consumers as promoting good health in a variety of ways, including increasing lactose content, controlling body weight, enhancing the immune system, improving digestion and absorption of nutrients, reducing or removing bad bacteria in the digestive tract, normalizing colon function (overcoming constipation and diarrhoea), reducing the risk of disease, contributing to detoxification and stress management, controlling blood cholesterol and blood pressure, and preventing cancer and osteoporosis. These and other health benefits are associated with probiotic bacteria, and yogurt is one of the food products containing probiotic cells. ${ }^{5-9}$ Studies have found that probiotics such as Lactobacillus and Bifidobacterium can have a positive influence on type 2 Diabetes Mellitus (DM), because probiotics can yield antidiabetic effects and suppress oxidative stress. ${ }^{10,11}$ However, probiotics that contain simple sugars cannot be used because they can increase blood glucose quickly. In addition to paying attention to antioxidant intake, controlling blood glucose is another crucial aspect of DM diet management. Therefore, attempts to replace simple sugars as sweeteners in probiotic drinks need to be made.

Extract of Stevia leaves (Stevia rebaudiana) is one of the low-calorie natural sweeteners derived from plants. ${ }^{12,13}$ Stevia dry leaf extract has a sweetness level 250-300 times higher than sucrose (cane sugar) has. ${ }^{14}$ Stevioside (3-10\% of leaf dry weight) and rebaudiosida (1-3\% of leaf dry weight) are 2 components of glycosides, which are sources of sweetness in the stevia leaf extract. ${ }^{15}$ Stevia products, recognized for use as nutritional supplements in the USA, are classified as GRAS (Generally Recognized As Safe). ${ }^{16}$ This plant has been used in many places across the world, such as Brazil and Paraguay, as a natural control for diabetes ${ }^{17}$ and weight control for people with obesity. ${ }^{18}$ Thanks to the sweetness and therapeutic properties of the leaves, stevia leaves have been used in traditional medicines for hundreds of years in South America. ${ }^{19}$ Thus, the addition of stevia sweetener in yogurt products could increase the

Rasayan J. Chem., 12(3), 1151-1156(2019)

http://dx.doi.org/10.31788/RJC.2019.1235365

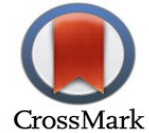


benefits of yogurt for health, especially for people with DM. The health benefits of yogurt can be increased through a variety of ways, including the variation of probiotic microorganisms addition, prebiotic ingredients and bioactive peptides produced during fermentation and storage. ${ }^{20-22}$ Yogurt products have rapidly diversified, as the number of people becoming aware of and developing a taste for healthy processed products has increased. Combining other foods with yogurt can supplement its nutritional content, for example, by adding bananas. Bananas are good for the immune system. as they contain nutrients from phosphorus, protein, fat, vitamin A, vitamin B, vitamin $\mathrm{C}$, and calcium. In addition, bananas have high levels of resistant starch and fiber. ${ }^{23}$ The addition of banana (Musa paradisiaca) in a yogurt product could improve its flavor so that consumer acceptance would be higher. Although many studies have been carried out on various flavors of yogurt, the presence of a new variant, for example, with the addition of bananas and natural stevia sugar, is needed to increase community acceptance of yogurt products. This study aims to examine the effects of adding kepok banana (Musa paradisiaca forma typical) and stevia sugar to yogurt on the quality of the product. The addition of kepok banana flavor is expected to produce good and economical yogurt.

\section{EXPERIMENTAL}

The process of making yogurt was carried out using a yogurt maker (size 16x16x14 cm, stainless steel, 1L capacity). Cow's milk $(200 \mathrm{ml})$ was pasteurized by resting on a hot plate at a temperature of $80^{\circ} \mathrm{C}$ for ten minutes. Skim milk (5\%) was then gradually added and stirred for five minutes, after which the temperature of the mixture was allowed to decrease to $42^{\circ} \mathrm{C}$. After the milk got cold, a mixture of bacterial starter (Lactobacillus bulgaricus and Streptococcus thermophillus) was added with the variation of 8-12 ml, then fermented for four, six, and eight hours at $42^{\circ} \mathrm{C}$ in the yogurt maker. The yogurt was tested by analyzing its $\mathrm{pH}$ and lactic acid levels. After fermentation was complete, $0.4 \%$ stevia sweetener and $40 \mathrm{mg}$ of the mashed banana fruit were added, after which aroma, color, taste, and texture organoleptic tests were carried out.

\section{Effect of Fermentation Time on Lactic Acid Levels}

\section{RESULTS AND DISCUSSION}

The fermentation process is said to be successful if lactic acid is formed, which is indicated by the formation of $\mathrm{CO}_{2}$ gas resulting from fermentation reactions with microbes Lactobacillus bulgaricus and Streptococcus thermophillus. The effect of fermentation time on lactic acid levels in yogurt is shown in Figure 1. Yogurt bacteria need suitable conditions, especially temperatures, to grow. Generally, bacteria grow well in warm places; yogurt bacteria grow quickly in a temperature of $42^{\circ} \mathrm{C}$. Both types of bacteria will break down lactose (milk sugar) into lactic acid and various components of aroma and flavor. Lactobacillus bulgaricus plays a role in aroma formation, Streptococcus thermophillus in yogurt flavor formation. ${ }^{24}$ As Figure-1 shows, the longer the fermentation time, the higher the level of lactic acid produced: at the time of fermentation, the lactic acid bacteria undergo a glucose change; therefore, a longer fermentation time will produce an even higher level of lactic acid. ${ }^{25}$ At 4 hours of fermentation, the yogurt, using $8 \mathrm{ml}, 10 \mathrm{ml}$, and $12 \mathrm{ml}$ of starter bacteria, had lactic acid levels of $0.34,0.4$, and $0.54 \%$, respectively. The lactic acid level increased to $0.73-0.75 \%$ at 6 hours fermentation time. At 8 hours fermentation time and $8 \mathrm{ml}, 10 \mathrm{ml}$, and $12 \mathrm{ml}$ of starter bacteria, the yogurt samples produced lactic acid levels of 1.20, 1.24, and 1.77\%, respectively. As shown in Figure 1, the highest level of lactic acid was achieved using the $12 \mathrm{ml}$ bacteria starter at 8 hours incubation time. The more starter used, the higher the lactic acid content produced. This is due to the increased concentration of microbial activity of Lactobacillus bulgalicus and Streptococcus thermophillus, as the number of microbes increases, which contributes to the increase in the amount of lactic acid formed. The lactic acid content obtained from this study is in accordance with Indonesian national quality standards. In fact, the lactic acid level in the yogurt in this study is slightly higher than that in the previous study using banana peels, which produced $1.38 \%$ lactic acid in yogurt. ${ }^{26}$

\section{pH Test}

Lactic acid decreases the $\mathrm{pH}$ of milk, which means it increases the milk acidity, so that the casein becomes unstable and clots to form yogurt gel. Factors that cause a decrease in the life ability of probiotic 
organisms are closely related to a decrease in $\mathrm{pH}$ of the medium and the accumulation of organic acids as a result of its growth and fermentation. The final $\mathrm{pH}$ achieved at the end of yogurt fermentation is the most important factor that affects the survival and growth of lactic acid bacteria. An increase in the amount of acid excreted by the lactic acid bacteria occurs because of the process of acid accumulation in the substrate, which, in turn, increases the acidity of the substrate. The increased acid accumulation in this substrate can be identified from the decreasing substrate $\mathrm{pH}^{27}$ Table 1 shows the changes in $\mathrm{pH}$ of yogurt during the fermentation process.

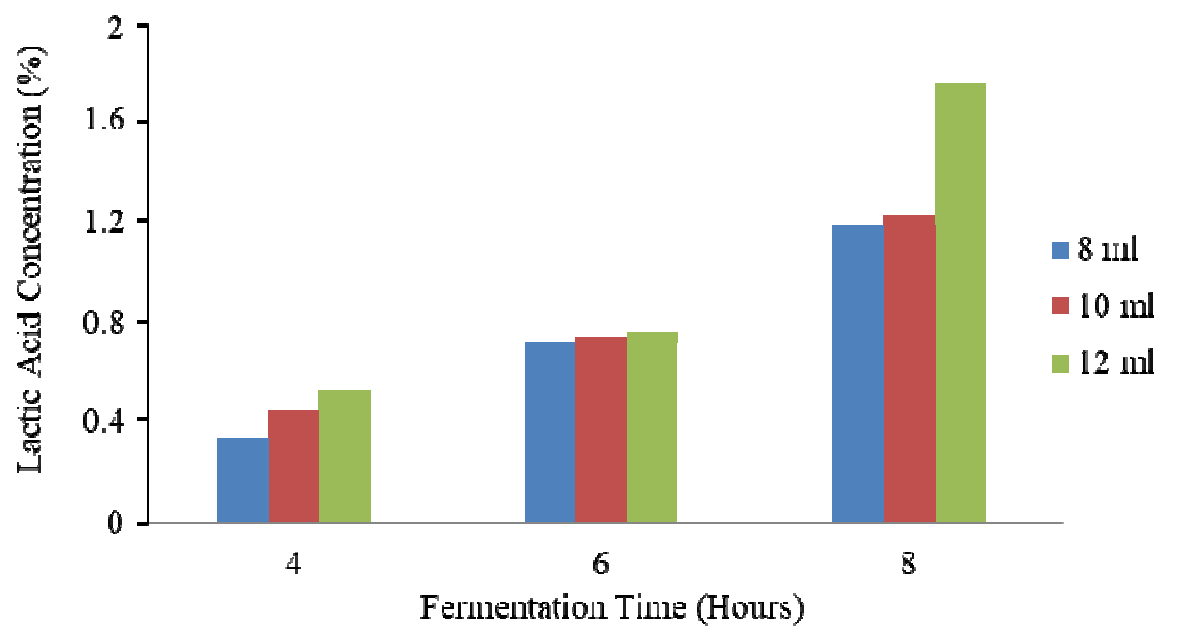

Fig-1: Effect of Fermentation Time on Lactic Acid Levels

Table-1: Changes in Yogurt pH During Fermentation

\begin{tabular}{c|c|c|c}
\hline \multirow{2}{*}{$\begin{array}{c}\text { Fermentation time } \\
\text { (hours) }\end{array}$} & \multicolumn{3}{|c}{ Starter (ml) } \\
\cline { 2 - 4 } & \multicolumn{3}{|c}{$\mathrm{pH}$} \\
\hline 4 & 5 & 10 & 12 \\
\hline 6 & 5 & 5 & 5 \\
\hline 8 & 4,5 & 4,5 & 4,5 \\
\hline
\end{tabular}

Table-1 shows that fermentation time has an effect on $\mathrm{pH}$, i.e., the longer the fermentation time, the lower the $\mathrm{pH}$ produced. During the fermentation process of milk by lactic acid bacteria, lactose is converted into lactic acid so that a product acidification process occurs. ${ }^{28}$ After four hours of fermentation, no change occurs in $\mathrm{pH}$ for any of the starters added. However, after eight hours of fermentation, the $\mathrm{pH}$ drops to 4.5 , which meets the requirement of the Indonesian quality standards for yogurt products.

\section{Organoleptic Testing}

Organoleptic testing is an assessment method that uses human sensory tools to inspect the physical appearance of a product. The results of this test indicate consumer acceptance of a product. The test includes the results of a panel assessment of the four product parameters: color, texture, aroma, and taste. In this study, the organoleptic test was only performed on the best yogurt samples, that is, those produced from the $12 \mathrm{ml}$ starter at eight hours fermentation. This test involved 20 panelists with a rating scale of 1 to 5. Table- 2 shows the results of the organoleptic test. The organoleptic test values obtained were then calculated using the hedonic test formula.

Where,

$$
\text { Average Quality Score } X=\sum X i / n
$$

$\mathrm{X}=$ average quality score

$\mathrm{Xi}=$ quality score of organoleptic test by panellist $\mathrm{i}$

$\mathrm{n}=$ number of panellists 
RASĀYAN J. Chem.

Vol. 12 | No. 3 |1151 - 1156| July - September | 2019

The results of the hedonic test are presented in Table-3. A higher hedonic scale reflects a higher rate of panelist acceptance of or preference for the yogurt product being tested.

Table-2: Organoleptic Test Data

\begin{tabular}{c|c|c|c|c}
\hline \multirow{2}{*}{$\begin{array}{c}\text { Panelist } \\
\text { order }\end{array}$} & \multicolumn{4}{|c}{ Score (1-5) } \\
\cline { 2 - 5 } & Color & Texture & Aroma & Taste \\
\hline 1 & 3 & 5 & 5 & 5 \\
\hline 2 & 3 & 4 & 5 & 4 \\
\hline 3 & 4 & 5 & 3 & 4 \\
\hline 4 & 3 & 5 & 3 & 4 \\
\hline 5 & 5 & 4 & 5 & 5 \\
\hline 6 & 4 & 4 & 4 & 3 \\
\hline 7 & 3 & 5 & 4 & 5 \\
\hline 8 & 3 & 4 & 3 & 5 \\
\hline 9 & 5 & 4 & 5 & 4 \\
\hline 10 & 5 & 4 & 5 & 5 \\
\hline 11 & 5 & 4 & 5 & 4 \\
\hline 12 & 5 & 3 & 5 & 5 \\
\hline 13 & 3 & 5 & 4 & 5 \\
\hline 14 & 5 & 5 & 5 & 4 \\
\hline 15 & 4 & 3 & 4 & 4 \\
\hline 16 & 5 & 4 & 4 & 4 \\
\hline 17 & 4 & 4 & 5 & 5 \\
\hline 18 & 3 & 5 & 5 & 5 \\
\hline 19 & 5 & 5 & 3 & 4 \\
\hline 20 & 4 & 5 & 4 & 4 \\
\hline
\end{tabular}

(Note: panelist acceptability score (1 dislike; 2 slightly dislike; 3 neutral; 4 quite like; 5 like))

Table-3: Hedonic Test Results of Yogurt

\begin{tabular}{c|c|c}
\hline Material & Organoleptic test & Hedonic value \\
\hline \multirow{4}{*}{ Yogurt } & Color & 4.05 \\
\cline { 2 - 3 } & Texture & 4.35 \\
\cline { 2 - 3 } & Aroma & 4.3 \\
\cline { 2 - 3 } & Taste & 4.4 \\
\hline
\end{tabular}

Colour is one of the factors that influence consumer acceptance of food products. Yogurt product with kepok banana addition has a milky white color. The average color preference score for the samples is 4.05 (quite like), and $25 \%$ of panelists liked the color of the yogurt product.

The texture of the yogurt produced determines whether the yogurt is of good quality. Good yogurt has a soft texture like porridge, not too runny and not too dense. The yogurt produced in this study had a soft, thick, smooth texture. The hedonic test results showed that the average preference score for texture was 4.35 (quite like), or $45 \%$ of panellists quite liked the texture. The water and protein content in milk are the most important factors affecting yogurt texture. An increased amount of protein will increase the amount of water that is bound and thus its gel firmness. ${ }^{29}$

The aroma of the yogurt with the addition of kepok banana consists of a typical yogurt aroma with a slight aroma of banana. The Lactobacillus bulgaricus bacteria play a role in the formation of the aroma of yogurt. The average preference for aroma in the samples was 4.3 (quite like), or $30 \%$ of the panellists quite liked the aroma.

Taste is one of the most important quality factors because it determines the level of consumer acceptance of the product. The taste of the yogurt with kepok banana addition was sour, with a combination of the typical tastes of yogurt and banana. The average score of preference for taste in the samples was 4.4 (quite like), or $50 \%$ of the panellists quite liked the taste. The panellists' assessment of the taste of yogurt 
RASĀYAN J. Chem.

Vol. 12 | No. 3 |1151 - 1156| July - September | 2019

tended to be subjective and was influenced by sensitivity and individual preference for the product. An acceptable taste for one age group does not necessarily apply to other age groups.

\section{CONCLUSION}

The optimum conditions to produce yogurt using Lactobacillus bulgaricus and Streptococcus thermophillus starter bacteria include eight hours of fermentation time, $12 \mathrm{ml}$ of starter bacteria, and $42^{\circ} \mathrm{C}$ of fermentation temperature. Under this condition, the obtained lactic acid was $1.77 \%$ with $\mathrm{pH} 4.5$. The color of the resulting yogurt was milky white, with soft, thick texture, a slight aroma of banana, and a distinctive taste of a yogurt-banana mixture. Hedonic values show that the panellists liked the yogurt produced, with preference values for color, texture, aroma, and taste of $4.05 ; 4.35 ; 4.3$; and 4.4, respectively.

\section{ACKNOWLEDGMENT}

The author would like to thank Universitas Syiah Kuala and the Ministry of Research, Technology and Higher Education of the Republic of Indonesia for the research grant, as well as Iin Silfiana and Ghitadia Ratmah for assisting the author in analyzing the research data.

\section{REFERENCES}

1. M.B. Roberfroid, The American Journal of Clinical Nutrition, 71(6), 1682S (2000), DOI: 10.1093/ajcn/71.6.1682S

2. S. Salminen, C. Bouley, M.C. Boutron, J.H. Cummings, A. Franck, G.R. Gibson, E. Isolauri, M.C. Moreau, M. Roberfroid, and I. Rowland, British Journal of Nutrition., 80(S1), S147 (1998), DOI: 10.1079/BJN19980108

3. A. Serafeimidou, S. Zlatanos, K. Laskaridis, A. Sagredos, Food Chemistry, 134(4), 1839 (2012), DOI: $10.1016 /$ j.foodchem. 2012.03.102

4. F.S. Vianna, A.C. Canto, B.R. da Costa-Lima, A.P.A. Salim, M.P. Costa, C.F. Balthazar, B.R. Oliveira, R.P. Rachid, R.M. Franco, C.A. Conte-Junior, and A.C. Silva, Small Ruminant Research, 149, 154 (2017), DOI: 10.1016/j.smallrumres.2017.02.013

5. P.H. Pradeep Prasanna and D. Charalampopoulos, International Journal of Dairy Technology, 72(1), 132 (2019), DOI: 10.1111/1471-0307.12568

6. C.S. Ranadheera, C. Evans, M. Adams and S. Baines, Food Research International, 49(2), 619(2012), DOI: 10.1016/j.foodres.2012.09.007

7. S.S. Senadeera, P.H.P. Prasanna, N.W.I.A. Jayawardana, D.C.S. Gunasekara, P. Senadeera and A. Chandrasekara, Heliyon, 4(11), e00955 (2018), DOI: 10.1016/j.heliyon.2018.e00955

8. H.Y. Yu, L. Wang and K.L McCarthy, Journal of Food and Drug Analysis, 24(4), 804 (2016), DOI:10.1016/j.jfda.2016.04.002

9. A.Y. Tamime and R.K. Robinson, Tamime and Robinson's yoghurt: Science and Technology, $3^{\text {rd }}$ ed., Elsevier (2007).

10. A.E.S. El Khamisy, Effect of bifidobacterium and lactobacillus acidophilus in diabetic rats. In The 5th Arab and 2nd International Annual Scientific Conference. April 8-9, Mansoura University Egypt (2009)

11. H.S. Ejtahed, J. Mohtadi-Nia, A. Homayouni-Rad, M. Niafar, M. Asghari-Jafarabadi and V. Mofid, Nutrition, 28(5), 539, (2012), DOI: 10.1016/j.nut.2011.08.013

12. A.E. Abou-Arab, A.A. Abou-Arab and M.F. Abu-Salem, African Journal of Food Science, 4(5) 269 (2010).

13. R. Lemus-Mondaca, A. Vega-Gálvez, P. Rojas, K. Stucken, C. Delporte, G. Valenzuela-Barra, R.J. Jagus, M.V. Agüero and A. Pasten, Journal of Applied Research on Medicinal and Aromatic Plants, 11, 37 (2018), DOI: 10.1016/j.jarmap.2018.10.003

14. N. Mishra, Journal of Natural Science Research, 1(3) 1 (2011).

15. L. Buchori, Reaktor, 11(2) 57 (2007), DOI: 10.14710/reaktor.11.2.57-60

16. S.K. Goyal, G.R. Samsher and R.K. Goyal, International Journal of Food Sciences and Nutrition, 61(1), 1 (2010), DOI: 10.3109/09637480903193049 
RASĀYAN J. Chem.

Vol. 12 | No. 3 |1151 - 1156| July - September | 2019

17. P.B. Jeppesen, S. Gregersen and C.R. Poulsen, Metabolism, 49(2), 208 (2000), DOI: 10.1016/S0026-0495(00)91325-8

18. M. Suttajit, U. Vinitketkaumnuen and U. Meevatee, Environmental Health Perspectives, 101(suppl 3), 53 (1993), DOI: 10.1289/ehp.93101s353

19. V. Chatsudthipong and C. Muanprasat, Pharmacology and Therapeutics, 121(1), 41(2009), DOI: 10.1016/j.pharmthera.2008.09.007

20. S. Amirdivani and A.S. Baba, LWT-Food Science and Technology, 44(6), 1458(2011), DOI: 10.1016/j.lwt.2011.01.019

21. A.P. Marafon, A. Sumi, D. Granato, M.R. Alcântara, A.Y. Tamime and M.N. Oliveira, Journal of Dairy Science, 94(11), 5330 (2011), DOI: 10.3168/jds.2011-4366

22. A.A. El-Fattah, S. Sakr, S. El-Dieb and H. Elkashef, LWT, 98, 390(2018), DOI: 10.1016/j.lwt.2018.09.022

23. T.S. Kahlon and G. E. Smith, Food Chemistry, 101(3), 1046(2007), DOI: 10.1016/j.foodchem.2006.02.059

24. F.G. Winarno, Bahan Tambahan Makanan, Pusat Antar Universitas Pangan dan Gizi, Institut Pertanian Bogor, Bogor (1990).

25. B. Misrianti, Pengaruh Penambahan Sukrosa Pada Pembuatan Whey Kerbau Fermentasi terhadap Penghambatan Bakteri Patogen, Skripsi, Fakultas Perternakan, Universitas Hasanuddin, Makassar (2013).

26. F.Y. Silalahi, Fermentasi Fruitghurt dengan Variasi Kulit Buah Sebagai Upaya dalam Pemanfaatan Limbah Cair Buah, Skripsi, Fakultas Teknik Universitas Diponegoro, Semarang (2010).

27. Ermina Syainah, Sari Novita and Rusmini Yanti, Jurnal Skala Kesehatan, 5(1), 1 (2014).

28. M. Brueckner-Guehmann, A. Benthin and S. Drusch, Food Hydrocolloids, 86, 146 (2019), DOI: 10.1016/j.foodhyd.2018.03.019

29. M. Saxelin, R. Korpel and A. Mayra Makinen, Functional dairy products, In: G. Smith, (Ed.), Dairy Processing: Improving Quality, Woodhead Publishing Limited, Cambridge England. CRC Press LLC, Boca Raton, Boston, New York, Washington, DC, p 229 (2003).

[RJC-5365/2019] 